\title{
Operative and fluoroscopy times in pediatric supracondylar humeral fracture surgery: A comparision between lateral and cross $K$-wire fixation techniques
}

\section{Pediyatrik suprakondiler humerus kırığında ameliyat ve floroskopi süresi: Lateral ve çapraz $\mathrm{K}$ teli tespiti tekniklerinin karşılaştırılması}

\author{
Hüseyin Tamer URSAVAŞ ${ }^{1}$, Mustafa İNCESU ${ }^{2}$, Gökhan ILYAS ${ }^{3}$ \\ ${ }^{1}$ İzmir Atatürk Ĕ̆itim ve Araştırma Hastanesi, İzmir, Türkiye \\ ${ }^{2}$ Izmir Tepecik Eğitim ve Araştırma Hastanesi, İmir, Türkiye \\ ${ }^{3}$ Kütahya Tavşanlı Devlet Hastanesi, Kütahya, Türkiye
}

\section{ABSTRACT}

\begin{abstract}
Objective: Although various treatment options have been described for treating this injury, in our study common types of treatment methods for 132 Gartner Type III supracondylar humerus fractures were examined. Cross pinning and Lateral Pinning (Lateral Divergent or Dorgan's Lateral pinning) methods were included and fluoroscopy time, reduction time and pinning time were examined among other parameters.

Methods: From January 2013 to January 2014, we retrospectively included all children between 2 and 12 years of age who had surgery for Gartland type III supracondylar humerus fracture within 12 hours after the injury. From 132 patients, 68 patients were in cross-pinning group and 64 patients were in lateral pinning group which consisted of 31 patients in the divergent pinning and 34 patients in Dorgan's type pinning group. Minimum follow-up time was 6 months after surgery and operation time, fluoroscopy time, reduction time, pinning time, neurovascular status of the extremity before and after treatment, Flynn criteria and postoperative complications were evaluated among other parameters. Results: In both groups satisfactory results were obtained according to Flynn criteria. Application of lateral pinning techniques lasted statistically significantly longer to achieve final pinning configuration than cross-pinning group $(p: 0,007)$. Though not statistically significant fluoroscopy time and total surgery time were longer in the lateral pinning. In subgroup analysis there weren't any statistically difference in any compared parameter between lateral divergent pin placement and Dorgan's lateral pin placement. Two patients, who were treated with cross- pinning technique had ulnar palsy which completely resolved conservatively at fifth month postoperatively.

Conclusion: It takes more attempt thus more time to achieve good configuration when lateral pinning methods are sellected to treat Gartland type 3 injuries. In the other hand iatrojenic ulnar nerve injury is a problem with cross pinning technique.
\end{abstract}

Keywords: Dorgan, pin, floroscopy, divergant, supracondylar, humerus, pediatric

$\ddot{\mathbf{O Z Z}}$

Amaç: Bu yaralanma için çeşitli tedavi yöntemleri tanımlanmışsa da çalışmamızda 132 Gartner tip III kırık için sıklıkla kullanılan tedavi yöntemleri incelenmiştir. Capraz telleme ve lateralden telleme (Lateral diverjan veya Dorgan metodu) yöntemleri dahil edilerek floroskopi süresi, redüksiyon süresi ve tel tespiti süresi birçok diğer parametreyle birlikte incelenmiştir.

Yöntem: Ocak 2013'ten Ocak 2014'e kadar 2 ile 12 yaş arası Gartland tip III suprakondiler humerus kırı̆̆ ${ }_{1}$ sonrası 12 saat içinde cerrahi geciren tüm hastalar calısmaya alındı. Yüz otuz iki hastadan 68 'i çapraz telleme grubundayken, 64 hasta lateralden telleme grubunu oluşturmaktaydı. Lateral telleme grubu 31 diverjan telleme grubu ile 34 Dorgan tipi telleme grubundan oluşmaktayd. Cerrahi sonrası minimum takip süresi 6 ay olmakla beraber, ameliyat süresi, floroskopi süresi, redüksiyon süresi, tel tespit süresi, tedavi öncesi ve sonrası nörovasküler durum, Flynn kriterleri ve ameliyat sonrası komplikasyonlar diğer paramatrelerle beraber değerlendirildi.

Bulgular: Her iki grupta da Flynn kriterlerine göre tatmin edici sonuçlar alınmıştır. Lateralden k teli tespit yöntemleri kullanıldığında çapraz telleme grubuna göre tel tespiti süresi açısından istatistiksel olarak daha uzun sürede ameliyatın son haline ulaşılmıştır (p:0,007). Lateral k teli tespitinde floroskopi ve ameliyat süresi daha uzun sürse de istatistiksel olarak anlamlı değildi. Altgrup analizlerinde lateral diverjan tel tespitiyle Dorgan yöntemi tel tespiti karşlaştırıldığında herhangi bir parametrede istatistiksel fark saptanmadı. Çapraz telleme yöntemi kullanılan iki hastada ulnar palsi mevcuttu ancak beşinci ayda konservatif olarak tamamen gerilediği gözlemlendi.

Sonuç: Gartland tip 3 yaralanmaların tedavisinde iyi bir tel dizilimi elde etmek için lateralden telleme yöntemleri kullanıldı̆̆ında daha fazla deneme ve dolayısıyla daha fazla vakit gerekmektedir. Diğger taraftan iatrojenik ulnar sinir yaralanması çapraz telleme ile ilişkili bir sorundur.

Anahtar kelimeler: Dorgan, tel, floroskopi, diverjan, suprakondiler, pediatrik
Alındığı tarih: 19.05 .2017

Kabul tarihi: 19.06 .2017

Yazışma adresi: Uzm. Dr. Hüseyin Tamer Ursavaş, İzmir Atatürk Eğitim ve Araştırma Hastanesi 2. Ortopedi Servisi, Karabağlar 35350 İzmir / Türkiye

e-mail: htamerursavas@gmail.com 


\section{INTRODUCTION}

Treatment of supracondylar humeral fractures in children is a common practice for an orthopedic surgeon who works at a Level 1 trauma center. Various treatment options have been described for treating this injury. In our study common types of treatment methods for 132 Gartner Type III supracondylar humerus fractures are examined. Cross pinning and Lateral Pinning (Lateral Divergent or Dorgan's Lateral pinning) methods are included and fluoroscopy time, reduction time and pinning time are examined among other parameters ${ }^{(1-3)}$.

\section{PATIENTS and METHODS}

From January 2012 to January 2013, 156 children between 2 and 12 years of age had surgery in our institution for the supracondylar humerus fracture within 12 hours after the injury. Twenty-four patients were lost to follow-up or had missing data. All patients had Gartland type III humerus supracondylar fracture, 68 patients were in cross-pinning group and 64 patients in the lateral pinning group which consisted of 31 patients in the divergent pinning and 34 patients in Dorgan's group. All medical records and radiograms were retrospectively evaluated before surgery, intraoperatively, before, and three months after pin removal. The parametres as age, and gender of the patients, laterality, and type of the fracture (posteromedial or posterolateral), operation time, fluoroscopy time, reduction time, pinning time, neurovascular status of the extremity before and after reduction, pin configuration, Flynn criteria and postoperative complications were evaluated.

Patients who had neuorologic or vascular problems before surgery were excluded. Patients with open and concomitant fractures, and those aged less than 2, and more than 12 years of age were excluded from the study. All included patients had been treated with closed reduction and pinning techniques as shown in the literature (Figures $1 \mathrm{a}, \mathrm{b}$ and $\mathrm{c})^{(1-3)}$.
Most of the patients had their casts removed at third, and fourth weeks, and then practiced full ROM exercises.

Surgery was done under general anesthesia mostly under iv ketamine administration which was dosed up to $4 \mathrm{mg} / \mathrm{kg}$. All patients were positioned supine on a fracture table and closed reduction was performed under the fluoroscopic guidance. When closed reduction was achieved, then percutaneous fixation with either crossed pinning or lateral pinning was done according to surgeon's preferred treatment. A member out of the surgical team noted the time spent for fracture reduction, pin fixation, fluoroscopy imaging and surgery. Fluoroscopy time in seconds and counts were also obtained from the fluoroscopy machine itself. All the patients were assesed carefully for vascular impairment and neurological status before and after surgery. During postoperative follow- up period postoperative complications as pin site infection and pin loosening complications were assesed.

The results were tabulated as frequency distribution for different qualitative values. Using the standard version of the SPSS program v. 21, as quantitative variablesthe arithmetic means and standard deviations were calculated. Comparisons between those with and without satisfactory outcomes were done using v2 (chi-square) test of significance. Correlation between groups was assesed with partial correlation test.

\section{RESULTS}

Both groups had satisfactory results according to the Flynn criteria (Table 1). There weren't any significant difference between groups regarding age, and gender of the patients, laterality, and type of fracture (posteromedial or posterolateral), Flynn criteria and postoperative complications (Table 1). Lateral pinning techniques significantly took more pinning time to have final pinning configuration than crosspinning group (p: 0,007) (Table 2). Although fluoroscopy time and total surgery time were longer, but ot 
Table 1. Baseline characteristics of 132 patients.

\begin{tabular}{|c|c|c|c|}
\hline Baseline Characteristics & Lateral Pinning (n: 64) & Cross Pinning (n:68) & P Value \\
\hline Male Sex (\% of patients) & $38(59,4 \%)$ & $43(63,2 \%)$ & $>0,5$ \\
\hline Age (years, mean value) & $5,34 \pm 2,98$ & $7,03 \pm 2,81$ & $>0,5$ \\
\hline \multicolumn{4}{|l|}{ Side (\% of patients) } \\
\hline Left & $40(62,5 \%)$ & $47(69,1 \%)$ & \multirow[t]{2}{*}{$>0,5$} \\
\hline Right & $24(37,5 \%)$ & $21(30,8 \%)$ & \\
\hline \multicolumn{4}{|l|}{ Types of Displacement } \\
\hline Posteromedial & $33(51,6 \%)$ & $41(60,3 \%)$ & \multirow[t]{2}{*}{$>0,5$} \\
\hline Posterolateral & $31(48,4 \%)$ & $27(39,7 \%)$ & \\
\hline \multicolumn{4}{|l|}{ Flynn Criteria } \\
\hline Excellent & 56 & 54 & \multirow[t]{4}{*}{$>0,5$} \\
\hline Good & 6 & 9 & \\
\hline Fair & 2 & 5 & \\
\hline Poor & 0 & 0 & \\
\hline Postoperative Complications & 2 Ulnar Deficits & none & $>0,5$ \\
\hline
\end{tabular}

Table 2. Time spent for fluoroscopic imaging, fracture reduction, krischner wire fixation and surgery.

\begin{tabular}{lccc}
\hline & $\begin{array}{c}\text { Lateral Pinning } \\
\text { Median } \pm \mathbf{I Q R} *\end{array}$ & $\begin{array}{c}\text { Cross Pinning } \\
\text { Median } \pm \mathbf{I Q R} *\end{array}$ & P Value \\
\hline Fluoroscopy Count & $19 \pm 23,5$ & $17 \pm 11$ & 0,608 \\
Fluoroscopy Time (seconds) & $23 \pm 28,5$ & $21 \pm 14$ & 0,661 \\
Reduction Time (minutes) & $10,5 \pm 20$ & $13 \pm 10$ & 0,155 \\
Pinning Time (minutes) & $13,1 \pm 10,0$ & $9,34 \pm 2,81$ & 0,007 \\
Surgery Time (minutes) & $25 \pm 24$ & $22 \pm 12$ & 0,505 \\
& & & \\
\hline
\end{tabular}

* IQR: Inter Quartile Range

statistically significant in the lateral pinning technique group (Table 2).

In the cross-pinning group there were 43 boys (63.2\% of 68$)$, and 41 of them had posteromedially displaced fractures $(60,3 \%)$. According to Flynn criteria 54 of them had achieved excellent (79.4\%), 9 of them good $(13.2 \%)$ and 5 of them fair $(7.3 \%)$ operative results. In lateral pinning group there were 38 boys (59.4\% of 64$)$, and 33 of them had posteromedially displaced fractures (51.6\%). According to Flynn criteria 56 of them had achieved excellent (87,5\%), 6 of them good $(9,4 \%)$ and 2 of them fair $(3,1 \%)$ operative results. In subgroup analysis there weren't any significant difference between lateral divergent pinning group and Dorgan's pinning group regarding age, and gender of the patients, laterality and type of fracture (posteromedial or posterolateral), operation time, fluoroscopy time, reduction time, Flynn criteria and postoperative complications.
Table 3. Correlation between variables.

\begin{tabular}{lccc}
\hline & Fluoroscopy & r* & p value \\
\hline Age & Time(sn) & $-0,007$ & 0,937 \\
Age & Reduction Time(m) & $-0,116$ & 0,210 \\
Age & Pinning Time(m) & $-0,044$ & 0,638 \\
Fluoroscopy Time(s) & Reduction Time(m) & 0,633 & $<0,001$ \\
Fluoroscopy Time(s) & Pinning Time(m) & 0,53 & $<0,001$ \\
Fluoroscopy Time(s) & Surgery Time(m) & 0,821 & $<0,001$ \\
& & & \\
\hline
\end{tabular}

$* r=$ partial correlation coefficient

Fluoroscopic imaging time, reduction time, pinning time and operative time were assesed with partial correlation test (Table 3). Fluoroscopy time was significantly correlated with reduction time, pinning time and operative time $(\mathrm{p}<0.001)$.

Two patients (2.9\% of 68 patients) who were treated with cross pinning technique had ulnar nerve deficit which completely resolved conservatively at postoperative fifth month. There weren't any postoperative radial or median nerve deficit, and any pin site infection or pin loosening was not observed during follow-up period.

\section{DISCUSSION}

Treating fractures of supracondylar humerus in children is a common practice for a pediatric orthopedic surgeon who works at a level 1 trauma center. There isn't an ideal method for treating this injury but 


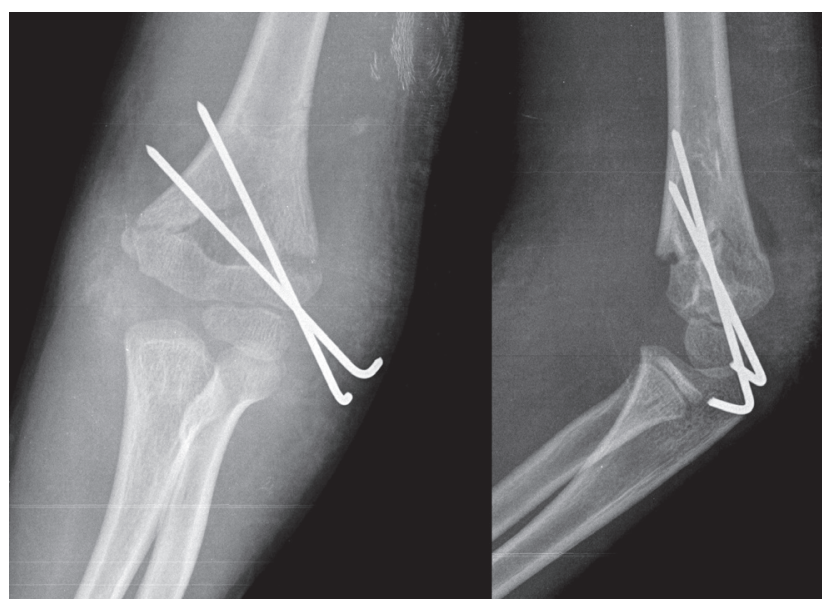

Figure 1a.

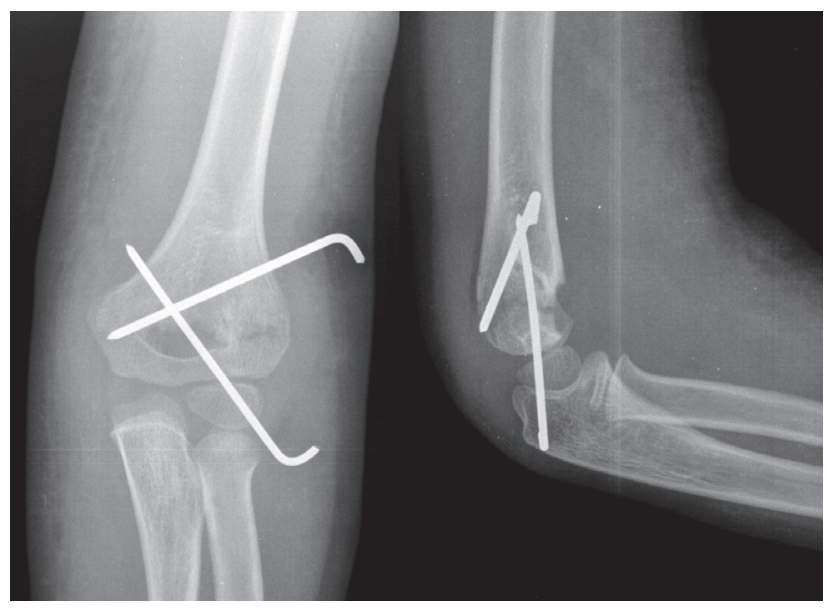

Figure 1b.

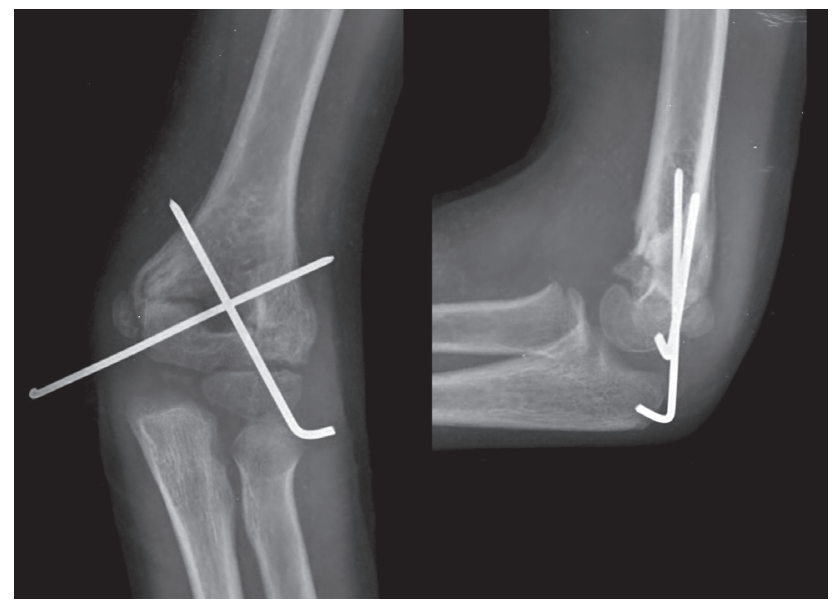

Figure 1c.

Gartland type 3 fractures are best treated by closed reduction and pin placement ${ }^{(4-6)}$. Gentle reduction and lateral pin placement have been advocated by various authors because medial pin placement is strongly associated with ulnar nerve dysfunction which has been documented in 5 to $11 \%$ of the cases ${ }^{(7-9)}$. In our series there were two complete ulnar nerve deficits all of which were in the cross-pinning group. These patients treated conservatively and their hand was fully functional in fifth month postoperatively without any additional surgery.

It is surgeon's choice to place another pin either laterally or medially as one lateral pin doesn't make stable construct as expected. This pin can be placed medially into the lateral cortex (cross pinning), later- ally into the medial cortex with some divergence (lateral divergent pinning) or laterally into the medial condyle (Dorgan's pinning method). Marshland and David's methods yielded stiffer constructs with medial or lateral crossed pins and above all a recent review on biomechanical studies showed no statistically significant differences between the two cross pins and two divergent lateral pins ${ }^{(10,11)}$. Memisoglu et al showed that Dorgan's lateral pin configuration has been found biomechanically as stable as cross pin configuration and superior to lateral pinning methods (12). As these two lateral entry pinning methods need good pin configuration for biomechanical stability, surgeons have to spent more time for surgery and they will use more fluoroscopy to achieve good con- 
H.T. Ursavaş et al., Operative and fluoroscopy times in pediatric supracondylar humeral fracture surgery: A comparision between lateral and cross K-wire fixation techniques

figuration ${ }^{(13-15)}$. Also multiple pinning attempts would be needed when good stability couldn't be achieved but young growing physis is vulnerable to multiple penetrations ${ }^{(16)}$.

Although age of the patient wasn't correlated with fluoroscopy, reduction or pinning time, it was clear that fluoroscopy time (in seconds) was significantly correlated with reduction, pinning and operative times (in minutes). With growing age, it didn't took extra time for reduction or pin placement but when more fluoroscopy needed in the operation room, the time spent for reduction, pinning and surgery also increased.

In this study we showed that placing an aditional lateral pin instead of medial pin to make cross pin configuration takes approximately additional $4 \mathrm{~min}-$ utes to achieve the final construct (Table 2). It is not a significant increase in time, but additional pin placement attempts result in good pin configuration or stable reduction. However, though not statistically significant, both surgical team and patient are exposed to extra gamma radiation; and fluoroscopy time increases while the surgeon tries to insert a lateral pin in the lateral pinning group ( $\mathrm{p}>0.05)$. Fluoroscopy was used for aproximately 22 seconds in 132 patients, while in some studies this time interval ranged between 25 and 55 seconds ${ }^{(13-15,17)}$.

\section{CONCLUSION}

It takes more time thus more attempts and more radiaton exposure to achieve good pin configuration when lateral pinning methods are sellected to treat Gartland type 3 injuries. On the other hand iatrojenic ulnar nerve injury is a problem with cross- pinning technique.

\section{REFERENCES}

1. Kazimoglu C, Cetin M, Sener M, Aguş H, Kalanderer O. Operative management of type III extension supracondylar fractures in children. Int Orthop. 2009;33(4):1089-94. https://doi.org/10.1007/s00264-008-0605-0

2. Hamdi A, Poitras P, Louati H, Dagenais S, Masquijo JJ,
Kontio K. Biomechanical analysis of lateral pin placements for pediatric supracondylar humerus fractures. J Pediatr Orthop. 2010;30(2):135-9. https://doi.org/10.1097/BPO.0b013e3181cfcd14

3. Shannon FJ, Mohan P, Chacko J, D'Souza LG. "Dorgan's" percutaneous lateral cross-wiring of supracondylar fractures of the humerus in children. J Pediatr Orthop. 2004;24(4):376-9. https://doi.org/10.1097/01241398-200407000-00006

4. Mulpuri K, Wilkins K. The treatment of displaced supracondylar humerus fractures: evidence-based guideline. J Pediatr Orthop. 2012;32:143-52. https://doi.org/10.1097/BPO.0b013e318255b17b

5. Cramer KE, Devito DP, Green NE. Comparison of closed reduction and percutaneous pinning versus open reduction and percutaneous pinning in displaced supracondylar fractures of the humerus in children. J Orthop Trauma. 1992;6(4):407-12. https://doi.org/10.1097/00005131-199212000-00002

6. Ladenhauf HN, Schaffert M, Bauer J. The displaced supracondylar humerus fracture: indications for surgery and surgical options: a 2014 update. Curr Opin Pediatr. 2014;26(1):64-9. https://doi.org/10.1097/MOP.0000000000000044

7. Lyons ST, Quinn M, Stanitski CL. Neurovascular injuries in type III humeral supracondylar fractures in children. Clin Orthop. 2000;376:62-7.

8. Rasool MN. Ulnar nerve injury after $\mathrm{k}$ wire fixation of supracondylar humerus fractures in childeren. J Pediart Orthop. 2001;22(2):157-61.

9. Joiner ER, Skaggs DL, Arkader A, Andras LM, LightdaleMiric NR, Pace JL, Ryan DD. Iatrogenicnerve injuries in the treatment of supracondylar humerus fractures: are we really just missing nerve injuries on preoperative examination? J Pediatr Orthop. 2014;34(4):388-92. https://doi.org/10.1097/BPO.0000000000000171

10. Marshland D, Belkoff S. Biomechanical analysis of posterior intrafocal pin fixation for the pediatric supracondylar humeral fracture. J Pediatr Orthop. 2014;34(1):40-4. https://doi.org/10.1097/BPO.0b013e31829b2ef7

11. Chen TL, He CQ, Zheng TQ, Gan YQ, Huang MX, Zheng YD, Zhao JT. Stiffness of various pin configurations for pediatric supracondylar humeral fracture: a systematic review on biomechanical studies. J Pediatr Orthop. 2015;24(5):389-99. https://doi.org/10.1097/BPB.0000000000000196

12. Memisoglu K, Kesemenli CC, Atmaca H. Biomechanical analysis of percutaneous all lateral pinning (Dorgan's technique) technique. J Biomechanics. 2011;44(Supplement 1): 10 . https://doi.org/10.1007/s00264-010-1090-9

13. Eismann EA, Wall EJ, Thomas EC, Little MA. Direct beam radiation exposure to surgeons during pinning of supracondylar humerus fractures: Does C-Arm position and the attending surgeon matter? J Pediatr Orthop. 2014;34(2):166-71. https://doi.org/10.1097/BPO.0000000000000086

14. Esen E, Doğramaci Y, Gültekin S, Görmeli G, Yildirim A, Kanatli U, Bölükbaşi S. Comparison of radiation exposure times in the treatment of pediatric supracondylar humeral fractures with open-closed reduction and internal fixation. Acta Orthop Traumatol Turc. 2009;43(5):400-5. https://doi.org/10.3944/AOTT.2009.400 
15. Kraus R, Joeris A, Castellani C, Weinberg A, Slongo T, Schnettler R. Intraoperative radiation exposure in displaced supracondylar humeral fractures: a comparison of surgical methods. J Pediatr Orthop. 2007;16(1):44-7. https://doi.org/10.1097/01.bpb.0000236238.87763.cf

16. Gottschalk et al. Biomechanical Analysis of Pin Placement for Pediatric Supracondylar Humerus Fractures: Does
Starting Point, Pin Size, and Number Matter? J Pediatr Orthop. 2012;32:445-51.

https://doi.org/10.1097/BPO.0b013e318257d1cd

17. Zhu YL, Hu W, Yu XB, Wu YS, Sun LJ. A comparative study of two closed reduction methods for pediatric supracondylar humeral fractures. J Orthop Sci. 2016;21(5):609-13.

https://doi.org/10.1016/j.jos.2016.04.013 